\title{
PROFIT MANAGEMENT IN ISLAM AND THE FACTORS
}

\author{
Devi Permatasari*
}

\begin{tabular}{l}
\hline * Affiliation: \\
Universitas Islam Sultan \\
Agung Semarang, \\
Indonesia \\
email: \\
devi_p@unissula.ac.id
\end{tabular}

* Affiliation:

Sultan

Indonesia

devi_p@unissula.ac.id

\begin{abstract}
:
Profit Management is a phenomenon that is influenced by various factors. Among them are such as information asymmetry and free cash flow. In Indonesia alone there are already cases of profit management from several years ago. This study aims to determine the influence of information asymmetry, and free cash flow on profit management practices in manufacturing companies listed on the Stock Exchange. The population of this study are the manufacturing companies that listed in Indonesia Stock Exchange (IDX) 2012-2016. The sampling technique used was purposive sampling method. The method of analysis used in this study using multiple linear regression. The total number of samples for this study are 180 companies. But, there are found 45 samples as outlier should be excluded from sample observation. So, the final samples for this study are 136 companies.

The results showed that the free cash flow has influence on profit management, and information asymmetry has no effect on profit management.
\end{abstract}

Keywords: Profit managements, Information Asymmetry, Free cash flow.

\section{INTRODUCTION}

The financial report is one of the important information for investors or creditors in making decisions related to investment shares. There are many things that need to be considered in taking the decision. One of them is to understand the content of the financial statements of the company. Financial statements becomes one of the important information sources for internal and external parties in assessing the ability of the company, that results profit.

Party Manager can reveal and report a profit in accordance with accounting policies applied in financial accounting standards as long as not violating the existing resource, in reporting profits should consider the requirements, but with more mastery makes a Manager manage the profit freely. Profit is arranged so that the financial statements look good by the parties concerned. The term is known as profit management. 
Profit management is a condition in which the managers benefit themselves by influencing the process of financial statements with the aim of reaching the level of a certain profit. It is also stated by Scott (2009) in Yamaditya (2014) that management profit is the decision of the Manager in selecting accounting policies to reach specific objectives either increase profits or reduce losses. However, according to Djakman (2003), profit management made by management are not the same as manipulating profit. Profit management is done by leverage the inherent weakness of the accrual accounting policies and still in accordance with Financial accounting standards. Hence, all the management profit is done without violating the standards of financial accounting, profit management practices are legitimate (Marzuqi and Achmad, 2010).

The perspective of accountants shows that management profit practice is not included in cheating (corruptive behavior) as long as all done based on accounting standards because accounting standards are seen as the norms that believed will not produce misleading information to users of financial statements (Marzuqi and Achmad, 2010).

Therefore, Islam considers both Manager and accountant must be honest, trustful, and honest in reporting the results of the financial statements to its users. Honesty is one of important thing in business because honesty will avoid yourself from the things that can harm either party. As Allah says in QS. Al-A'raf verse 85 " So fulfill the measure and weight and do not deprive people of their due".

Furthermore, Islam does not permit anyone (particularly in this business) to cheat/fraud in which of the deeds will impact the other party's detriment, as the word of God Almighty in the Qur'an An Nisa verse 29: "O you who have believed, do not consume one another's wealth unjustly but only [in lawful] business by mutual consent.".

Accounting information is a condition where there is an imbalance in obtaining

information between managers with stakeholders. Accounting information is important because accounting information has become the main source of information for management

in managing the company, investing, for investors and other parties. Yamaditya (2014) conveys that the asymmetry between agent and principal can pose opportunities for agents in manipulating the company's financial statements because the agent is more understand about internal information than the principal. As an agent, the Manager is responsible morally for optimizing the benefits of the stockholders (principal). But on the other hand managers also has an interest in maximizing their well-being, so it is possible for agents do not always act in the interest of the best principals. Therefore, the existence of asymmetry of information allowing the existence of conflict occurred between the agent and principal by utilizing the other party.

In Wiyadi, et.al (2016) suggests that the cause of managers done the profit management is because of a there is information gap (information asymmetry). The statement reinforced with research from Nariastiti and Ni Made, (2014) who discovered the existence of information asymmetry between positive affect toward the profit management. While according to Eden (2013) information asymmetry does not give positive impact toward profit management.

Furthermore, management profit can also be influenced by free cash flow. Free cash flow is the residual cash flow available for the company within a certain period. The treasuries usually rise conflict of interest between managers and shareholders. Managers usually prefer to 
invest more funds on projects that can generate profits. On the other hand, shareholders expect the rest of the funds are distributed so that will increase the prosperity of the shareholders.

Rahadyan and Agus (2015), find that free cash flow gives a positive impact on profit management. It is because companies with high cash flow surpluses are to do profit management since the importance of profit in the financial statements. And managers will report the financial report by showing the wealth of the company. Different results from Agustia (2013), free cash flow gives a negative effect on profit management. This is due to the company's free cash flow will incline to do the profit management, because although there are profit management, the company is able to increase its stock price.

\section{LITERATURE REVIEW}

\section{Agency Theory}

According to Jensen and Meckling (1976), the theory of Agency is the agency relationship as a contract between the principal (the shareholders) and agents (managers). The relationship between the employment contract the principal and the agent becomes difficult because of the difference in interests intertwined Differences that can lead to conflicts of interests of the Agency. Agency conflict occurs when the principal party could not ascertain whether the agent is acting in the interest of the principal. This can lead to the occurrence of asymmetry of information because the principal only know the State company limited reports provided by agents.

\section{The Influence Of Information Asymmetry Towards The Management Profit}

Information asymmetry is a condition where there is an imbalance in the obtaining of information between managers with stockholder. Agency theory explains that the sale of shares in the transaction, information about stock prices experienced the difference between belonging to agent and principal, where the agent is more knowing company information so that it can trigger in doing actions in accordance with interests in maximizing the utility. While the principals that have less information will find difficulty in overseeing the actions taken by management. This gives rise to the occurrence of profit management.

\section{H1: The positive effect of information asymmetry towards the Management Profit.}

\section{The Influence Of Free Cash Flow Terhadap Disclosure Of Profit Management}

White et al. (2003) into Agustia, (2013) revealed that the company can be said to be healthy when companies have a value of free cash flow that is big enough because with have free cash flow can be used for more growth, the payment debt, and dividends. The existence of free cash flow may cause differences of interest between agent and principal. When the principal wanted the rest of the funds are distributed, however unlike the agent who wished that the value of free cash flow is used for the growth of the company. Therefore, the relationship between free cash flow with Spider management occurs when the value of free cash flow in a company is not operated in maximizing the interests of shareholders. When managers choose to invest in projects that are not favorable to their own interests will lead to the low growth of the company. Therefore the management will tend to do the management profit so that the company can meet the categorized on a healthy level. 
h2: Positive Impacts of Free Cash Flow on Profit Management.

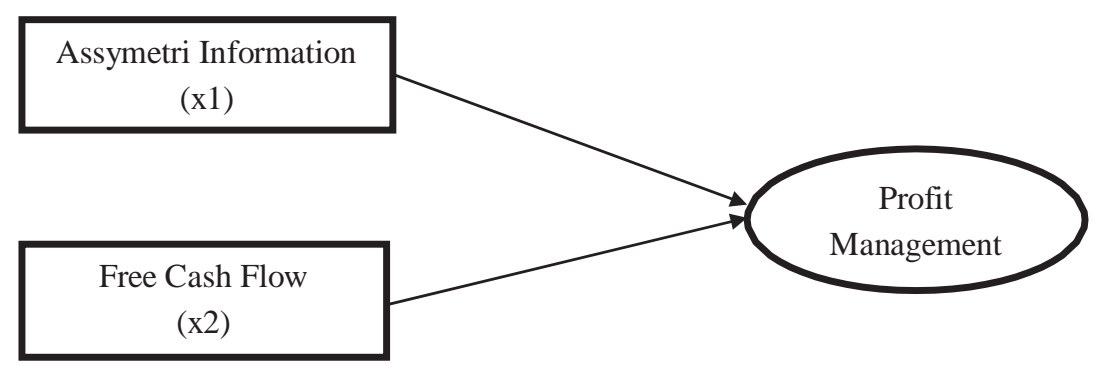

Figure 1

Research Model

\section{RESEARCH METHODOLOGY}

\section{Research Variable}

\section{Profi Management}

The measurement of management profit can be measured using the discretionary accrual.

Discretionary accrual is not normal happens due to an engineering manager of the company.

In measuring the discretionary accrual, should measure the total accrual first. According to (Pujiningsih, 2013) phases are used in measuring the accrued among others:

a. Calculate the accrual value estimated by OLS regression equations (ordinary least square):

TACt $/$ At- $1=\alpha 1(1 /$ At- 1$)+\alpha 2((\triangle$ REVt- $\triangle$ RECt $) /$ At- 1$)+\alpha 3($ PPEt $/$ At- 1$)+e$

Where:

$\alpha \quad$ : fitted coefficient obtained from regression results on calculations total accruals

TACt : total accruals of company $i$ in $t$ period

At-1 : total sample asset for company $i$ in the end of year $t-1$

REVt : income change of company $i$ from year $t-1$ to year $t$

RECt : debt change of company i from year $t-1$ to year $t$

PPEt : fixed assets (gross property plant and equipment) of company year $t$

e : error

b. Calculate nondiscretionary accrual model (NDA):

$\mathrm{NDAt}=\alpha 1(1 /$ At- 1$)+\alpha 2((\Delta \mathrm{REVt}-\Delta \mathrm{RECt}) / \mathrm{At}-1)+\alpha 3(\mathrm{PPEt} / \mathrm{At}-1)$

Notes:

NDAt : nondiscretionary accruals in year $\mathrm{t}$

$\alpha \quad$ : fitted coefficient obtained from regression result in total accruals calculation

c. Calculate discretionary accrual:

DACt: (TACt/ At-1) - NDAt

Notes:

DACt :discretionary accruals company $\mathrm{i}$ in the period of $\mathrm{t}$ 


\section{Assymetri Information}

Information asymmetry is a condition where there is an imbalance in the obtaining of information between managers with the stockholder. Information asymmetry is measured using bid ask spread. Bid-ask spread is the difference between the purchase price highest lowest selling price with stock traders. Information asymmetry is measured using bid ask spread (Putra et, al., 2014).

SPREAD $=\left(\right.$ Ask $\left.\left._{\mathrm{i}}, \mathrm{t}-\mathrm{Bid}_{\mathrm{i}}, \mathrm{t}\right) /\left(\mathrm{Ask}_{\mathrm{i}}, \mathrm{t}+\mathrm{Bid}_{\mathrm{i}}, \mathrm{t}\right) / 2\right\} \times 100$

Where:

Ask $_{\mathrm{i}}, \mathrm{t}$ : The highest ask price of company i stock happened in $\mathrm{t}$ year

Bid $_{i}, t$ : the lowest bid price of company $i$ stock happened in $t$ year

\section{Free cash flow}

White et al. (2003) in Agustia, (2013) revealed that the company can be said to be healthy when companies have a value of free cash flow that is big enough because with have free cash flow can be used for more growth, the payment debt, and accounting. This variable is calculated by using the formula of the Brigham and Houston (2010) in (Agustia, 2013).

Free cash flow $=$ NOPAT - net investment in operating capital

Notes:

Nopat (net operating profit after tax) $=$ EBIT $(1-$ tax rate)

Net capital investment operations $=$ Capital total $\mathrm{t}$ operatiom - total operating capital

Total operating capital = Net oprarting working capital + net fixed assets

Net oprarting working capital $=$ Smooth assets - current liabilities

\section{Sample Consideration}

The population that will be taken in this study i.e. the manufacturing company listed in BEI. The sampling technique used in this study i.e., purposive sampling techniques, namely the technique of sampling, based on certain criteria.

As for the criteria that will be used as the sample is as follows:

1. Manufacturing companies that have data of financial statements during the period of 2012-2016

2. Manufacturing companies that publish financial statements respectively during the period 2012-2016

3. Manufacturing company that serves a financial report in rupiah (IDR).

4. Manufacturing company did not suffer losses during the period of 2012-2016

5. Manufacturing company which has complete data variable-related research..

\section{Data Abalysis Technique}

Hypothesis testing in this study using multiple linear regression analysis model equations in this study is: 
$\mathrm{Q}=\alpha+\beta_{1} \cdot \mathrm{AI}_{\mathrm{it}}+\beta_{2} . \mathrm{FCF}_{\text {it }}+\mathrm{e}$

Notes:

Q : Profit Management

AI : Assymetri Information

FCF :Free Cash Flow

$\alpha \quad$ : Constants

$\beta 1-\beta 2$ : Regression Coefficient

e : Error

\section{RESULT AND DISCUSSION}

Statistic Descriptive Sample

The population in this research is the manufacturing companies listed on the Indonesia stock exchange during the period from 2012 to 2016. Tabulated results of which have been done terdapat 152 companies listed on the Indonesia stock exchange per year and who meet the criteria are as much as 36 of the company for 5 years so that the samples are 180 samples. The following is a sample distribution research:

\section{Table 4.1}

\section{Research Sample Determination}

\begin{tabular}{|c|l|r|}
\hline No & \multicolumn{1}{|c|}{ Notes } & Total \\
\hline 1. & The number of companies listed at the IDX per year & 152 \\
\hline 2. & Companies that do not fall into the category manufacturing company per year & $(20)$ \\
\hline 3. & The manufacturing company did not issue a financial report with the currency (IDR) & $(28)$ \\
\hline 4. & The company does not have the data lengkapuntuk research & $(23)$ \\
\hline 5. & The company does not earn a profit per year & $(37)$ \\
\hline 6. & The company does not publish stock prices per year & $(8)$ \\
\hline 7. & The Number Of Sample Enterprises & 36 \\
\hline & The Number Of Sample Enterprises in 5 years (2012-2016) & 180 \\
\hline & Outlier Data & $(45)$ \\
\hline & TOTAL OF DATA SAMPLE & 135 \\
\hline
\end{tabular}

Source : Secondary processed data, 2019

\section{Descriptive Statistic}

By using descriptive statistics give an overview of the data being viewed from the average (mean), standard deviation, maximum and minimum values of each of the variables used in this study. As for the result is as follows:

Table 1 Test Results Of Descriptive Statistics

\begin{tabular}{|l|r|r|r|r|r|}
\hline & $\mathrm{N}$ & \multicolumn{1}{|c|}{ Minimum } & Maximum & \multicolumn{1}{c|}{ Mean } & Std. Deviation \\
\hline Assymetri Information & 135 & .00 & 8.00 & 2.2273 & 2.11257 \\
Free Cash Flow & 135 & -391.00 & 373.00 & 7.4222 & 124.32345 \\
Profit Management & 135 & -.29 & .38 & .0345 & .11409 \\
Valid N (listwise) & 135 & & & & \\
\hline
\end{tabular}

Source : Secondary processed data, 2019 
normality Testing

Normality testing using normal probability plots graphs and Kolmogorov-Smirnov

Figure 2 Normality Testing Result

Normal P-P Plot of Regression Standardized Residual

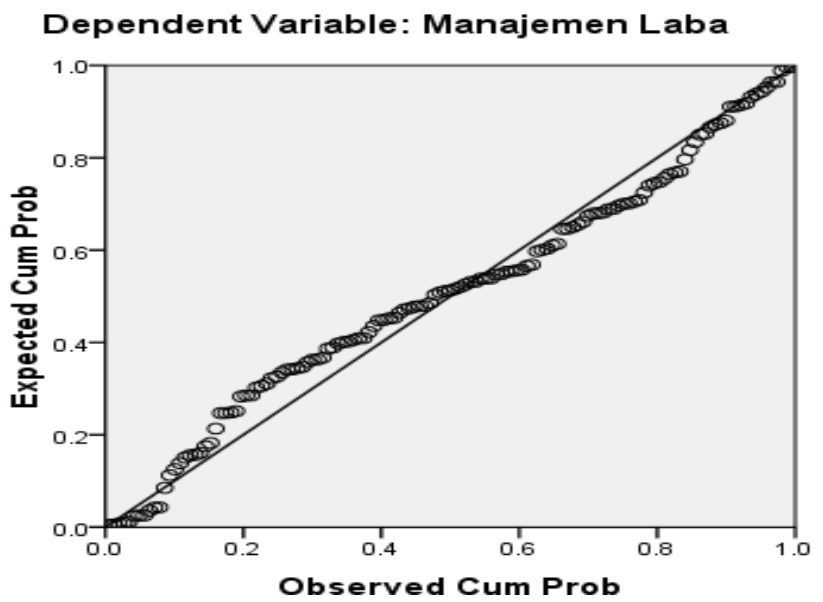

Source : Secondary processed data, 2019

Normality test results with a graph of normal probability plots the points spread around the diagonal line where this indicates that the data is normal.

In addition the result of Kolmogolrov Smirnov (K-S) as follows:

Table 2 Normality Testing Result

\begin{tabular}{|c|c|c|}
\hline \multicolumn{3}{|c|}{ One-Sample kolmogorov-Smirnov Test } \\
\hline & & Unstandardized Residual \\
\hline $\begin{array}{l}\mathrm{N} \\
\text { Normal } \\
\text { Parameters }^{\mathrm{a}} \\
\text { Most Extreme } \\
\text { Differences } \\
\text { Kolmogorov-S } \\
\text { Asymp. Sig. (2 }\end{array}$ & $\begin{array}{l}\text { Mean } \\
\text { Std. Deviation } \\
\text { Absolute } \\
\text { Positive } \\
\text { Negative } \\
\text { hirnov Z } \\
\text { tailed) }\end{array}$ & $\begin{array}{r}135 \\
.0000000 \\
.10618225 \\
.087 \\
.066 \\
-.087 \\
1.015 \\
.254\end{array}$ \\
\hline Test dis & is $\mathrm{No}$ & \\
\hline
\end{tabular}

Source : Secondary processed data, 2019

Based om the table above, the normality testing results show that Asymp sig value is $0,254>0,05$, thus it can be concluded that the data has normally distributed.

\section{Heteroscedasticity Test Results}

Heteroscedasticity test is used to test whether the model regression residual variance inequality occurred from one to the other observations. To find out whether there is heteroscedasticity used a test scatterplot glejser test and as in the following figures and tables. 
Figure 3. Scatterplot Test Result

Scatterplot

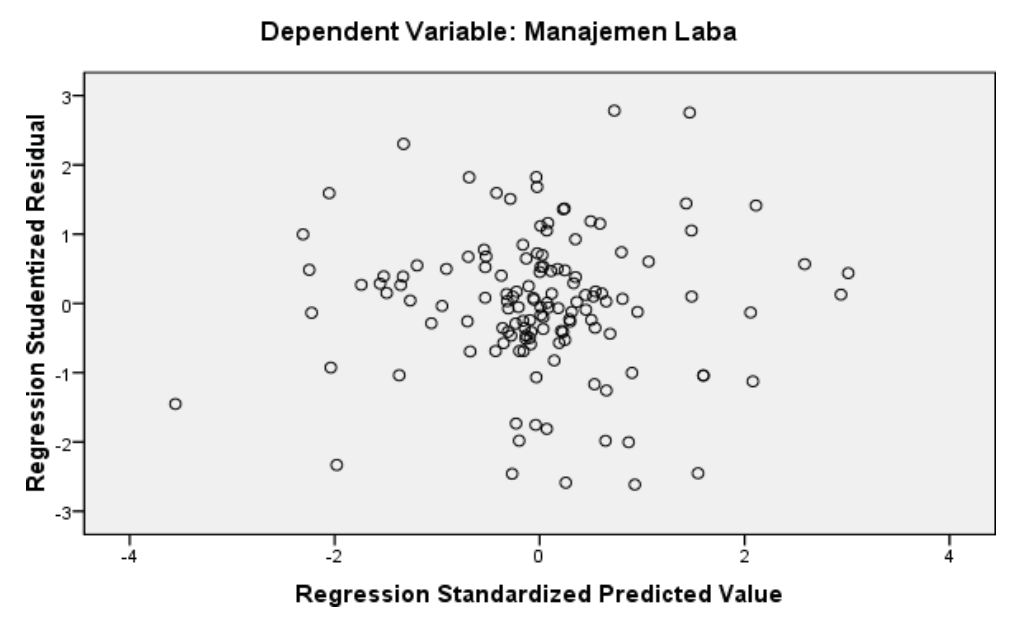

Source : Secondary processed data, 2019

Based on the above heteroscedasticity test shows that the points spread above and below the 0 on the $\mathrm{Y}$ axis so that the problem does not occur in a regression model heteroscedasticity.

In addition to these research trials glejser. This testing criteria is if the probability 0.05 > value then does not happen heteroscedasticity. (Ghozali, 2011).

Table 3 Glejser Test Result

Coefficients $^{\mathrm{a}}$

\begin{tabular}{|c|c|c|c|c|c|}
\hline \multirow[b]{2}{*}{$\mathrm{B}$} & \multicolumn{2}{|c|}{$\begin{array}{c}\text { Unstandardized } \\
\text { Coefficients }\end{array}$} & \multirow[t]{2}{*}{$\begin{array}{l}\text { Standardized } \\
\text { Coefficients }\end{array}$} & \multirow[b]{2}{*}{$\mathrm{T}$} & \multirow[b]{2}{*}{ Sig. } \\
\hline & Std. Error & Beta & & & \\
\hline (Constant) & .073 & .025 & & 2.900 & .004 \\
\hline Asimetri Informasi & -.001 & .003 & -.035 & -.400 & .690 \\
\hline Free Cash Flow & $-2.422 \mathrm{E}-5$ & .000 & -.042 & -.458 & 648 \\
\hline
\end{tabular}

a. Dependent Variable: ABSUI

Source : Secondary processed data, 2019

From the table above it can be seen that all variables have the value of sig more than Thus it can be concluded that not happen heteroscedasticity.

\section{Multicollinearity Test Results}

Multicollinearity test is used to find out whether or not there is a Multicollinear between the free variables (Ghozali, 2011). 
Table 4 Multicollinearity Test Result

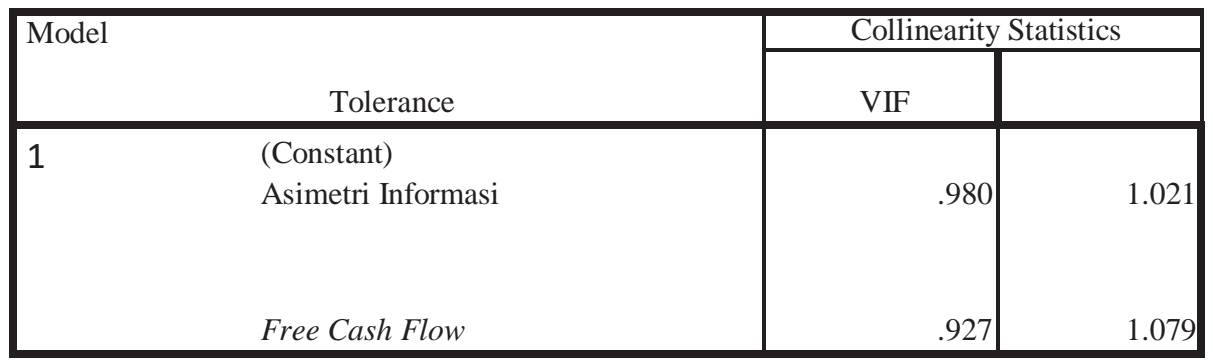

a. Dependent Variable: Manajemen Laba

Source : Secondary processed data,2019

Based on the results of the table above, it can be noted that all the variables are independent tolerance $0.1>$ number shows and VIF $<10$, this indicates that all the above doesn't happen independent variable multicollinearity.

\section{Autocorrelation Test Result}

Autocorrelation arises due to successive observation all the time related to each other (Ghozali, 2011). Below are the results from the test autocorrelation

\section{Table 5 Durbin-Watson Test Result}

\begin{tabular}{|l|cc|}
\multicolumn{2}{c|}{ Model Summary $^{\mathbf{b}}$} \\
\hline Model & Durbin-Watson & 1.499 \\
\hline 1 & & \\
\hline
\end{tabular}

a. Predictors: (Constant), Free Cash Flow, Asimetri Informasi, Leverage, Profitabilitas

b. Dependent Variable: Manajemen Laba

Source : Secondary processed data, 2019

table shows that $\mathrm{dL}$ and $\mathrm{dU}$ are 1,6584 and 1,7802. Baesd on regression analysis result, it can be taken that $\mathrm{D}-\mathrm{W}$ is 1,499 . Because $\mathrm{dw}>0$ and $\mathrm{dw}<\mathrm{dl}$ Therefore it can be known that there is no positive autocorrelation in this test.

Due to the positive autocorrelation problem occurs then the autocorrelation test done with test runs test. The following test results test run can be seen with the table below:

Table 6 Runs Test

\begin{tabular}{|l|r|}
\hline & Unstandardized Residual \\
\hline Test Value & .00340 \\
Cases $<$ Test Value & 67 \\
Cases $>=$ Test Value & 68 \\
Total Cases & 135 \\
Number of Runs & 69 \\
Z & .087 \\
Asymp. Sig. (2-tailed) & .931 \\
\hline
\end{tabular}

a. Median

Source : Secondary processed data, 2018 
The results of the test run show that the value of the Asmp. SIG (2-tailed) $>0.05$ which means it can be concluded that not happen autocorrelation.

\section{Multiple Linear Regression Analysis}

Multiple linear regression analysis was used to examine the influence of two or more independent variables the dependent variables against one (Ghozali, 2011).

Table 7 Multiple Linear Regression Result

\begin{tabular}{|c|c|c|c|c|c|}
\hline \multirow[t]{2}{*}{ Model } & \multicolumn{2}{|c|}{$\begin{array}{l}\text { Unstandardized } \\
\text { Coefficients }\end{array}$} & \multirow[t]{2}{*}{$\begin{array}{l}\text { Standardized } \\
\text { Coefficients }\end{array}$} & \multirow[b]{2}{*}{$\mathrm{T}$} & \multirow[b]{2}{*}{ Sig. } \\
\hline & Std. Error & Beta & & & \\
\hline $1 \quad$ (Constant) & .036 & .037 & & .967 & .335 \\
\hline Asimetri Informasi & -.004 & .004 & -.073 & -.883 & .379 \\
\hline Free Cash Flow & .000 & .000 & -.371 & -4.379 & .000 \\
\hline
\end{tabular}

a. Dependent Variable: Manajemen Laba

Source : Secondary processed data, 2019

From the table above it can be known that constant $\mathrm{b} 0=0.036$ this meaning is that information asymmetry, profitability, leverage, and free cash flow value is 0 , then the management profit value of 0.036. And the table above can be multiple linear regression equations are formulated as follows:

$\mathrm{Y}=0,036-0,004 \times 1+0,000 \times 2$

Multiple linear regression results above shows that:

1) Coefficient values of asymmetry information (X 1) is negative of-0.004, stating that by assuming the absence of any other variable, then when the asymmetry of information has increased, then the management profit decline.

2) Free cash flow coefficient Values (X 2) the positive value of 0.000 , stating that by assuming the absence of other variables, then in free cash flow has decreased, then management will experience increased profit.

\section{Determination Coefficient}

Table 8 Determination Coefficient Test Result

\begin{tabular}{|l|r|r|r|r|}
\hline Model & \multicolumn{1}{|c|}{ R } & R Square & Adjusted R Square & Std. Error of the Estimate \\
\hline 1 & .366 & .134 & .107 & .10780 \\
\hline
\end{tabular}

a. Predictors: (Constant), Free Cash Flow, Asimetri Informasi

b. Dependent Variable: Manajemen Laba

Source : Secondary processed data, 2018

Based on the table above, it can be noted that the value of the coefficient of determination (Adjusted R Square) is of 0.107 . This means that the variable information asymmetry and free cash flow together have an influence of $10.7 \%$ against management. While the rest of $89.3 \%$ are affected by other variables that are not included in the study. 


\section{Significant Simultaneous (Uji F)}

Analytical techniques used multiple regression data processing was performed using SPSS version 16 program rocks. The test results are obtained as follows:

Table 8hasil uji F

ANOVA $^{\mathrm{b}}$

\begin{tabular}{|ll|r|r|r|r|r|}
\hline Model & & Sum of Squares & Df & Mean Square & F & Sig. \\
\hline 1 & Regression & .233 & 4 & .058 & 5.020 & .001 \\
& Residual & 1.511 & 130 & .012 & & \\
Total & 1.744 & 134 & & & \\
\hline
\end{tabular}

a. Predictors: (Constant), Free Cash Flow, Asimetri Informasi

b. Dependent Variable: Manajemen Laba

Source : Secondary processed data, 2019

From the calculation result can we know that $\mathrm{F}$ calculates 5.020 with the significance of 0.001 . The significance of value smaller than 0.05 can thus be inferred that the asymmetry of information, profitability, leverage, and free cash flow is the simultaneous effect on profit management.

\section{The influence of Information Asymmetry towards the Management Profit}

Based on the results of analysis and hypothesis testing above show that the asymmetry of information has value significance $0.379 \mathrm{IE}$ greater than 0.05 and the value of the beta coefficient of-0.004 with negative direction. This suggests that the absence of significant effects of information asymmetry between against profit management.

The results of this study indicate that information asymmetry does not give any effect towards the management of profits due to the possibility of an error in a previous financial reporting that is not in accordance with the qualitative rules. The rule is of relevance in the financial information presented in the financial report, neutral and complete in the presentation of the financial statements, and financial statements are presented should have the power of appeal.

The results of this study are consistent with previous research conducted by Eden (2013) which concluded that information asymmetry does not affect significantly to profit management. and also research from Kusumawati, Shinta, and Rina (2013) stating that no information asymmetry influence on profit management

\section{The Influence of Free Cash Flow towards the Management Profit}

Based on the results of analysis and hypothesis testing above shows that free cash flow is a value 0.000 significance that is smaller than 0.05 and beta coefficient value of 000 . in a positive direction. This shows that the existence of significant influence between the free cash flow against management. In other words, the higher surplus the higher free cash flow in the company, then the manager would freely use free cash in the company to an investment that is not profitable for the company and will result in a decline in the value of the company. So to cover up his actions, Manager doing management profit so that the effect of the use of the 
negative free cash flow inside can be covered with a good performance management.

The research indicates that companies that have free cash flow will do profit management. The results of this research are consistent with research conducted by Kodriyah, (2017) that says free cash flow positive effect against management. In addition research and Agus Rahadyan (2015) also found that free cash flow effect on profit management.

\section{conclusion}

Profit management conducted by management is not the same as manipulating profits (Djakman, 2003). Profit management is done by leveraging the inherent disadvantage of the accrual accounting policies and still in accordance with Financial accounting standards. Hence, all the management profit was done without violating the standards of financial accounting, profit management practices are legitimate, that is a good operations management (Marzuqi and Achmad, 2010). Furthermore, based on the results of data analysis and discussion has been parsed, then it can be drawn to the conclusion that the variable information asymmetry has no effect against management. While free cash flow effect on profit management.

\section{REFERENCES}

Agustia, D. (2013). Pengaruh Good Corporate Governance, Free Cash Flow, dan Leverage Terhadap Manajemen Laba. Jurnal Akuntansi Dan Keuangan, Vol.15, No.1 Issn 14110288 Print, 27-42.

Astuti, T., \& Walansendoew, O. C. (2013). Analisis Pengaruh Diversifikasi Perusahaan Terhadap Manajemen Laba (Studi Pada Perusahaan Manufaktur yang Terdaftar Pada Bursa Efek Indonesia Periode 2012-2015). Skripsi.

Fatmawati, \& Djajanti, A. (2015). Pengaruh Ukuran Perusahaan, Profitabilitas dan Financial Leverage Terhadap Praktik Perataan Laba Pada Perusahaan Manufaktur yang Terdaftar di Bursa Efek Indonesia. Jurnal Akuntasi. Issn :2337-5965 Vol.2. No.3.

Firdaus, I. (2013). Pengaruh Asimetri Informasi dan Capital Adequac Ratio Terhadap Manajemen Laba. Simposium Nasional Ekonomi Bisnis.

Ghozali, I. (2013). Aplikasi Analisis Multivariate dengan Program Spss. Semarang: Badan Penerbit Universitas Diponegoro.

Jensen, M., \& Meckling, W. (1976). Theory Of The Firm : Manajerial Behavior Agency Cost And Ownership Structure . Jurnal Of Financial Economics Vol 03 No.4 Pp 305-360.

Kodriyah. \& Anisah, F. (2017). Pengaruh Free Cash Flow Terhadap Manajemen Laba Pada Perusahaan Manufaktur di BEI. Jurnal Akuntansi Vol. 3 No. 2.

Kusumawati, Shinta, dan Rina (2013). Pengaruh Asimetri Informasi, dan Mekanisme Corporate Governance Terhadap Praktik Earning Manajement (Kajian Perbandingan Perusahaan yang Terdaftar Dalam Indeks Syariah dan Indeks Konvensional Bursa Efek Indonesia) Proceeding Seminar Nasional dan Call For Papers Sancall. 
Nariastiti, N., \& Ratnadi, N. D. (2014). Pengaruh Asimetri Informasi, Corporate Governance Dan Ukuran Perusahaan Pada Manajemen Laba. E-Jurnal Akuntansi Universitas Udayana 9-3.

Nugroho (2011). Analisis Pengaruh Likuiditas, Pertumbuhan Penjualan, Perputaran Modal Kerja, Ukuran Perusahaan, Dan Leverage Terhadap Profitabilitas Perusahaan (Studi Pada Perusahaan Manufaktur yang Terdaftar di BEI Tahun 2005-209. Skripsi.

Pujiningsih, A. I. (2011). Pengaruh Struktur Kepemilikan, Ukuran Perusahaan, Praktik Corporate Governance dan Kompensasi Bonus Terhadap Manajemen Laba (Studi Empiris Pada Perusahaan Manufaktur yang Terdaftar Di Bursa Efek Indonesia Periode 2007-2009). Jurnal Akuntansi.

Rahadyan W., S. \& Agus Purwanto (2015). Pengaruh Surplus Free Cash Flow Dan Mekanisme Good Corporate Governance Terhadap Manajemen Laba. Jurnal Of Accounting Vol 4, No 2.

Wildarman, Herawati, \& Resti, Y. (2013) Pengaruh Profitabilitas, Leverage, Dan Asimetri Informasi Terhadap Manajemen Laba (Study Empiris Pada Perusahaan Manufaktur Yang Terdaftar di Bursa Efek Indonesia Periode 2009-2013). Jurnal Akuntansi.

Wiyadi, Trisnawati, R., Puspitasari, N., \& Sasongko, N. (2016). Pengaruh Asimetri Informasi, Leverage, dan Profitabilitas Terhadap Manajemen Laba Riil Pada Perusahaan Manufaktur di Indonesia. The $3^{\text {rd }}$ University Research Colloquium 2016.

Yamaditya, V. (2014). Pengaruh Asimetri Informasi, Leverage, dan Ukuran Peusahaan Terhadap Praktik Manajemen Laba (Studi Empiris Pada Perusahaan Manufaktur yang Terdaftar di BEI Tahun 2011-2013. Skripsi.

Yatulhusna, N. (2015). Pengaruh Profitabilitas, Leverage, Umur, Dan Ukuran Perusahaan Terhadap Manajemen Laba (Studi Empiris pada Perusahaan Manufaktur yang Terdaftar di Bursa Efek Indonesia Periode 2010-2013). Skripsi. 